\title{
Normative Organizational Commitment and its Effects on Employee Retention
}

\author{
Mouhamadou Sow, DBA \\ Faculty, City University of Seattle, USA \\ Professor, National American University, USA \\ Faculty, University of Phoenix, USA \\ Peter Anthony, EdD \\ Faculty-Dissertation Chair, Walden University, USA \\ Moussa Berete, DBA \\ Faculty-Dissertation Mentor, Capella University, USA
}

Received: December 26, 2015 Accepted: January 17, 2016

doi:10.5296/ber.v6i1.9018 URL: http://dx.doi.org/10.5296/ber.v6i1.9018

\begin{abstract}
Given the strategic benefit of retaining employees, the need for identifying factors that drive employee retention has attracted the attention of both scholars and practitioners in the past few decades. Grounded on the self-determination theory of motivation, the purpose of this quantitative study with correlational design was to examine he relationship between normative commitment and turnover intention among healthcare internal auditors in the United States. The results of a correlational analysis using data from 92 healthcare internal auditors member of AHIA show a negative and significant relationship between normative commitment and turnover intention $(\mathrm{r}=-.248, \mathrm{p}=.03)$.
\end{abstract}

Keywords: Organizational, Normative Commitment, Turnover Intention, Employee Retention

\section{Introduction}

Given the role of organizational commitment in the relationship between individuals and their organizational, the concept of organizational commitment has become a major topic of 
management and behavioral sciences (Rehman, Shareef, Mahmood, \& Ishaque, 2012). Understanding organizational commitment has attracted the interest of many scholars and practitioners (Morrow, 2011). Organizational commitment is a leading driver of many organizational behaviors including turnover intention (Taing, Granger, Groff, Jackson, \& Johnson, 2011).

Depending on the reasons why employees commit to their organizations, three different types of organizational commitment exist. Affective commitment occurs when employees their employing organization because they are satisfied and they feel the sense of belonging to the organization (Kimura, 2013). Continuance commitment occurs when employees stay in the organization because of recognition of the costs associated with leaving the organization (Balassiano \& Salles, 2012). Finally, normative commitment occurs when employees commit because of a moral obligation to stay in the organization and employees feel that they must stay in the organization (Balassiano \& Salles, 2012). These three types of organizational commitment may have different effects on employees' behavior. Therefore, it is important to study them separately. The current study focused on one type of organizational commitment, which is normative commitment and examined how this type of organizational commitment affect turnover intention among healthcare internal auditors in the United States.

\section{Purpose of the Study}

The purpose of this quantitative study with correlational design was to examine he relationship between normative commitment and turnover intention among healthcare internal auditors in the United States. The sample of the study was of 92 internal auditors who are member of the association of healthcare internal auditors (AHIA) and working in the United States. Achieving the purpose of the study included seeking the answer to the following research question.

RQ: To what extend does normative commitment relate to turnover intention among U.S. healthcare internal auditors?

The process of answering this research question involved testing the following null and alternate hypotheses.

$H 1_{0}$ : There is no significant relationship between normative commitment and turnover intention among U.S. healthcare internal auditors.

$H 1_{\mathrm{a}}$ : There is a significant relationship between normative commitment and turnover intention among U.S. healthcare internal auditors.

Turnover is one of the most challenging issues facing the auditing profession in the United States healthcare industry (Lafleur et al., 2012). The objective of this study was to contribute to the solution of turnover issues of internal auditors in the United States healthcare industry. Given the cost related to employee turnover and the value of audit quality, a study on factors potentially affecting turnover intention of auditors could have a significant business impact in the healthcare industry. Previous researchers have shown that turnover of healthcare internal auditors is likely to affect the quality of audit in healthcare (Chi et al., 2013). Since healthcare 
is not only a business problem, but also a relevant social matter, a study on the turnover of healthcare internal auditors is likely to have a positive social impact as well as a great contribution to business practices.

\section{Theoretical Framework}

The basis of this study was the self-determination theory of motivation. This theory, advanced by Deci and Ryan (1985) has its foundation in the psychology of human motivation and personality. The self-determination theory provides a viable framework for studying employee turnover (Forrier, Sels, \& Stynen, 2009). The core of self-determination theory of motivation focuses on the identification and satisfaction of three psychological needs including: (a) autonomy, (b) competence, and (c) relatedness (Deci \& Ryan, 1985). Autonomy refers to the feeling of free choice and relatedness refers to the feeling of value and appreciation (Meyer \& Maltin, 2010). The competence need refers to the need of employees' needs to process the skills and capabilities needed to perform their tasks (Martin \& Hill, 2013). Self-motivation theorists consider the need of every individual or organization to make choice without interference of others (Robson, Schlegelmilch, \& Bojkowszky, 2012). Those psychological needs lead to the three types of organizational commitment including: (a) affective commitment, (b) continuance commitment, and (c) normative commitment (Meyer $\&$ Parfyonova, 2010). The focus of this study was to examine how normative commitment relate to the turnover intention of healthcare internal auditors in the United States.

\section{Literature Review}

This section covers a brief review on current and previous literature related to the relationship between normative commitment and turnover intention. The literature review has two part. The first part covers a discussion on organizational commitment in general with a focus on normative commitment. The second part of the review covers a brief discussion of turnover intention.

\section{Organizational Commitment}

Given the role of organizational commitment in the relationship between individuals and their organizational, the concept of organizational commitment has become a major topic of management and behavioral sciences (Rehman, Shareef, Mahmood, \& Ishaque, 2012). Understanding organizational commitment has attracted the interest of many scholars and practitioners (Morrow, 2011). Organizational commitment is a leading driver of many organizational behaviors including turnover intention (Taing, Granger, Groff, Jackson, \& Johnson, 2011). The focus of this subsection of the literature review is to present some definitions of organizational commitment.

The past three decades have witnessed a growing number of studies on organizational commitment (Soumyaja, Kamalanabhan, \& Bhattacharyya, 2011). The literature offers a variety of definitions of organizational commitment (Arora, Nuseir, Nusair, \& Arora, 2012). Organizational commitment refers to the desire and the willingness of an employee to contribute to the success of an organization (Sani, 2013). The definition of Sani overlooked the reasons of commitment. A year earlier, Ellenbecker and Cushman (2012) considered the 
reasons of commitment and they defined organizational commitment as the various reasons that drive an employee's attachment to an organization. Some of these reasons included moral attachment, emotional attachment, and obligation (Balassiano \& Salles, 2012; Ellenbecker \& Cushman, 2012). Dey (2012) went beyond an employee's attachment and willingness to help the organization succeed, and added the employee's willingness to stay with the organization.

Several workplace-related factors including job satisfaction drive an employee's organizational commitment (Qamar, 2012). In a quantitative study, Srivastava (2013) collected data from 247 middle level managers in the private sector to examine how job satisfaction relates to relationship organizational commitment. The results showed a positive relationship between job satisfaction and organizational commitment. Albrecht (2012) also supported the driving effect of job satisfaction on organizational commitment.

Other work related factors such as job stressors and emotional exhaustion also drive organizational commitment (Kemp, Kopp, \& Kemp, 2013). In a mixed methods study involving 435 professional truck drivers, Kemp et al. examined how job stressors and emotional exhaustion related to organizational commitment. The results showed that both job stressors and emotional exhaustion related positively to organizational commitment.

In addition to job satisfaction, job stressors, and emotional exhaustion, several other factors such as security, health, work conditions, and human development may drive organizational commitment (Farjad \&Varnous, 2013). In a study involving managers and deputies of a communication company and an infrastructure company, Farjad and Varnous examined the effect of various workplace factors on organizational commitment. The results indicated that security, health, work conditions, and human development have strong impacts on organizational commitment. Workplace physical environment was found to be a significant driver of an employee's organizational commitment (McGuire \& McLaren, 2009).

Gallato et al. (2012) found leadership and organizational culture as drivers of job satisfaction, which is a driver of organizational commitment. Other researchers such as Khan, Hafeez, Rizvi, Hasnain, and Mariam (2012) and Leroy, Palanski, and Simons (2012) also indicated leadership style as a driver of organizational commitment. Behavioral integrity also drives organizational commitment (Fritz, O'Neil, Popp, Williams, \& Arnet, 2013; Leroy et al., 2012). Gumusluoglu, Karakitapoğlu-Aygüna, and Hirst (2013) introduced procedural justice as another driver of organizational commitment.

Depending on the reasons why employees commit to their organizations, three different types of organizational commitment exist. Affective commitment occurs when employees their employing organization because they are satisfied and they feel the sense of belonging to the organization (Kimura, 2013). Continuance commitment occurs when employees stay in the organization because of recognition of the costs associated with leaving the organization (Balassiano \& Salles, 2012). Finally, normative commitment occurs when employees commit because of a moral obligation to stay in the organization and employees feel that they must stay in the organization (Balassiano \& Salles, 2012). Table 1 contains the three types of organizational commitment. 
Table 1. Types of Organizational Commitment

\begin{tabular}{|l|l|}
\hline Types of commitment & Reasons for committing \\
\hline Affective & Desire, feeling of belonging \\
\hline Continuance & Lack of alternatives, consequences of leaving \\
\hline Normative & Moral obligations \\
\hline
\end{tabular}

The current study focused on normative commitment. Normative commitment is the extent to which employees have a moral obligation to stay in the organization and employees feel that they must stay in the organization (Balassiano \& Salles, 2012). In addition to the desire to commit and the consequence related to leaving, employees may also commit to their employing organizations because they feel the moral obligation to commit (Gelaidan \& Ahmad, 2013). Similarly, organizational culture was positively related with moderating the relationship between transactional leadership and normative commitment to change, and had a stronger effect. In the context of normative commitment, employees are committed because of some moral obligations (Balassiano \& Salles, 2012). Normative commitment occurs when an individual feels the need to reciprocate after receiving some benefits from an organization (Gelaidan \& Ahmad, 2013).

\section{Turnover Intention}

Turnover intention is defined as an employee's intention to voluntarily leave an organization (Jehanzeb, Rasheed, \& Rasheed, 2013). The opposite of turnover intention is intent to stay (Costen \& Salazar, 2011). Given the current global trends such as increased competition among organizations, high demand of skilled employees, and the cost of turnover, retaining employees, especially qualified ones has become more important than ever (Davidson, Timo, \& Wang, 2010). Various reasons drive employees' intention to leave their organizations. One of the most known drivers include organizational commitment (Galletta, Portoghese, \& Battistelli, 2011; Rashid \& Raja, 2011; van Dyk \& Coetzee, 2012; Yücel, 2012). However, it is important to note that different types of organizational commitment have different effects on employee retention or turnover intention (Yücel, 2012). Job satisfaction is another commonly known driver of turnover intention (Kim \& Jogaratnam, 2010). In addition, Long and Thean (2011) found leadership style as a significant driver of employee turnover intention. Some researchers have also found workplace justice as a significant driver of turnover intention (Cantor, Macdonald, \& Crum, 2011).

\section{Methodology}

The purpose of this study was to examine he relationship between normative commitment and turnover intention among healthcare internal auditors in the United States. The research method used in this study was quantitative and the design was correlational. The study has one independent variable, which is normative commitment and one dependent variable, which s turnover intention. 


\section{MlMacrothink}

Business and Economic Research

ISSN 2162-4860

2016, Vol. 6, No. 1

The independent variable, normative commitment was measured using the revised version of the three-components model (TCM) employee commitment survey (Meyer \& Allen, 2004). The TCM employee commitment survey is an 18-item survey instrument. Among the 18 items, 6 items serves to measure affective commitment, 6 items to measure continuance commitment, and 6 items to measure normative commitment. This study used on the normative commitment part of the survey. A reliability study of the TCM employee commitment survey conducted by Meyer, Stanley, Herscovitch, and Topolnytsky (2002) showed an average reliability score of .82 for affective commitment. Participants responded to the TCM employee commitment survey questions on a 7-point Likert-type scale; 1 = strongly disagree; $2=$ disagree; $3=$ slightly disagree; 4 = undecided; $5=$ slightly agree; $6=$ agree; and $7=$ strongly agree. Each participant's normative commitment score represented the sum of the score of the six items related to affective commitment.

The dependent variable, turnover intention was measured using the Turnover Intention Scale from the Michigan Organizational Assessment Questionnaire to measure turnover intention (Cammann et al., 1983). The Turnover Intention Scale is a 7-point Likert-type scale that includes three items. The turnover intention scale has a reliability score of .78 (Owolabi, 2012). In this survey, each participant had one score, which was the sum of the scores of the three items included in the instrument.

Participants of this study included members of the Association of Healthcare Internal Auditors (AHIA). Using Survey Monkey, we sent the survey AHIA members through the association's electronic newsletter. The survey was open for 15 days. A total of 105 responses were received and 13 were rejected due to missing information.

After collecting the data, we organized the raw data into three column: a column for participant identification number, a column for normative commitment score, and a column for turnover intention score. The participant identification number was a number from 1 to 92 assigned to each participant based on the order in which the survey was completed. This number does not have any link with the participant's personal information; the survey was unanimous.

\section{Analysis of the Data}

The raw data consisted of 105 records; 13 records were rejected due to incomplete information. The analysis was thus conducted using 92 records. Descriptive analysis was conducted to describe the distribution of each variable. The independent variable, normative commitment scores had a mean of 23.7 and standard deviation of 7.3. The dependent variable, turnover intention scores ranged from 3 to 21 , with a mean of 11.5 and a standard deviation of 5.5. Table 2 show the distribution of the data.

Table 2. Descriptive Analysis

\begin{tabular}{|l|l|l|l|}
\hline & $\mathrm{N}$ & Mean & SD \\
\hline Turnover Intention & 92 & 11.5 & 5.5 \\
\hline Normative Commitment & 92 & 23.7 & 7.3 \\
\hline
\end{tabular}


Correlation coefficient was computed to examine the relationship between normative commitment and turnover intention. The goal was to test the following null hypothesis:

H10: There is no significant relationship between normative commitment and turnover intention among U.S. healthcare internal auditors.

Using the Bonferroni approach to control Type 1 error, a p value of less than .05 was required for significance. The result of the correlation analysis show that the correlation between normative commitment and turnover intention was negative and significant $(\mathrm{r}=-=.248, \mathrm{p}=.03)$. Therefore, the null hypothesis was rejected. This indicated that there is a negative and significant relationship between normative commitment and turnover intention.

\section{Summary}

The purpose of this quantitative study with correlational design was to examine he relationship between normative commitment and turnover intention among healthcare internal auditors in the United States. Normative commitment is the commitment that occurs when employees have moral attachment to their organizations. The results indicated that the greater the normative commitment, the lower the turnover intension. These results suggest that organizational leaders should try to create a moral link between their organizations and their employees. Normative commitment is likely to be easily promoted in family businesses where people have a strong attachment to the organization because of the family legacy or because of the bound they have with their coworkers. Evidence also shows that providing some benefits to employees develop normative commitment in them.

\section{References}

Albrecht, S. L. (2012). The influence of job, team and organizational level resources on employee well-being, engagement, commitment and extra-role performance. International Journal of Manpower, 33, 840-853. http://dx.doi.org/10.1108/01437721211268357

Arora, N., Nuseir, M. T., Nusair, T. T., \& Arora, R. (2012). Study-based moderators influencing the relationship between organizational climate and employee's organization commitment. EuroMed Journal of Business, 7, 201-220. http://dx.doi.org/10.1108/14502191211245615

Balassiano, M., \& Salles, D. (2012). Perceptions of equity and justice and their implications on affective organizational commitment: A confirmatory study in a teaching and research institute. Brazilian Administration Review, 9, 268-286. Retrieved from http://dx.doi.org/10.1590/S1807-76922012000300003

Cammann, C., Fichman, M., Jenkins, G. D., \& Klesch, J. R. (1983). Assessing the attitudes and perceptions of organizational members. In S. Seashore, E. E. Lawler, P. H. Mirvis, \& C. Cammann (Eds.). Assessing organizational change: A guide to methods, measures, and practices (pp. 71-138). New York, NY: Wiley.

Cantor, D. E., Macdonald, J. R., \& Crum, M. R. (2011). The influence of workplace justice perceptions on commercial driver turnover intentions. Journal of Business Logistics, 32, 
274-286. http://dx.doi.org/10.1111/j.2158-1592.2011.01022.x

Chi, W., Hughen, L., Lin, C., \& Lisic, L. L. (2013). Determinants of audit staff turnover: Evidence from Taiwan. International Journal of Auditing, 17, 100-112. http://dx.doi.org/10.1111/j.1099-1123.2012.00459.x

Costen, W. M., \& Salazar, J. (2011). The impact of training and development on

Employee job satisfaction, loyalty, and intent to stay in the lodging industry. Journal of Human Resources in Hospitality \& Tourism, 10, 273-284. http://dx.doi.org/10.1080/15332845.2011.555734

Davidson, M. C. G., Timo, N., \& Wang, Y. (2010). How much does labor turnover cost? A case study of Australian four and five star hotels. International Journal of Contemporary Hospitality Management, 22, 451-466. http://dx.doi.org/10.1108/09596111011042686

Deci, E. L., \& Ryan, R. M. (1985). Intrinsic motivation and self-determination in human behavior. New York, NY: Plenum. http://dx.doi.org/10.1007/978-1-4899-2271-7

Dey, T. (2012). Predictors of organizational commitment and union commitment: A conceptual study. IUP Journal of Organizational Behavior, 11, 62-75. Retrieved from http://www.iupindia.in/

Ellenbecker, C. H., \& Cushman, M. (2012). Home healthcare nurse retention and patient outcome model: Discussion and model development. Journal of Advanced Nursing, 68, 1881-1893. http://dx.doi.org/10.1111/j.1365-2648.2011.05889.x

Farjad, R. H., \& Varnous, S. (2013). Study of relationship of quality of work life (QWL) and organizational commitment. Interdisciplinary Journal of Contemporary Research in Business, 4, 449-456. Retrieved from http://ijcrb.webs.com/

Forrier, A., Sels, L., \& Stynen, D. (2009). Career mobility at the intersection between agent and structure: A conceptual model. Journal of Occupational \& Organizational Psychology, 82, 739-759. http://dx.doi.org/10.1348/096317909X470933

Fritz, J., O’Neil, N., Popp, A., Williams, C., \& Arnett, R. (2013). The influence of supervisory behavioral integrity on intent to comply with organizational ethical standards and organizational commitment. Journal of Business Ethics, 114, 251-263. http://dx.doi.org/10.1007/s10551-012-1345-z

Gallato, C. G., Rashid, S., Suryasaputra, R., Warokka, A., Reamillo, K. G., \& bin Abdullah, H. H. (2012). Fostering niches among SMEs in Malaysia through organizational commitment, leadership, organizational culture and job satisfaction. Journal of Innovation Management in Small \& Medium Enterprises, 3(2), 1-12. http://dx.doi.org/10.5171/2012.511352

Galletta, M., Portoghese, I., \& Battistelli, A. (2011). Intrinsic motivation, job autonomy and turnover intention in the Italian healthcare: The mediating role of affective commitment. Journal of Management Research, 3(2), 1-19. http://dx.doi.org/10.5296/jmr.v3i2.619

Gelaidan, M. H., \& Ahmad, H. (2013). The factors effecting employee commitment to 
change in public sector: Evidence from Yemen. International Business Research, 6, 75-87. http://dx.doi.org/10.5539/ibr.v6n3p75

Gumusluoglu, L., Karakitapoğlu-Aygüna, Z., \& Hirst, G. (2013). Transformational leadership and R \& D workers' multiple commitments: Do justice and span of control matter? Journal of Business Research, 66, 2269-2278. http://dx.doi.org/10.1016/j.jbusres.2012.02.039

Jehanzeb, K., Rasheed, A., \& Rasheed, M. F. (2013). Organizational commitment and turnover intentions: Impact of employee's training in private sector of Saudi Arabia. International Journal of Business \& Management, 8, 79-90. http://dx.doi.org/10.5539/ijbm.v8n8p79

Kemp, E., Kopp, S. W., \& Kemp, E. C. (2013). Take this job and shove it: Examining the influence of role stressors and emotional exhaustion on organizational commitment and identification in professional truck drivers. Journal of Business Logistics, 34, 33-45. http://dx.doi.org/10.1111/jbl.12008

Khan, V., Hafeez, M. H., Rizvi, S. M. H., Hasnain, A., \& Mariam, A. (2012). Relationship of leadership styles, employees commitment and organization performance (A study on customer support representatives). European Journal of Economics, Finance \& Administrative Sciences, 49, 133-143. Retrieved from http://www.europeanjournalofeconomicsfinanceandadministrativesciences.com/

Kim, K., \& Jogaratnam, G. (2010). Effects of individual and organizational factors on job satisfaction and intent to stay in the hotel and restaurant industry. Journal of Human $\begin{array}{lllll}\text { Resources in Hospitality } \quad \text { \& } & \text { Tourism, } & 9, & 318-339 .\end{array}$ http://dx.doi.org/10.1080/15332845.2010.487043

Kimura, T. (2013). The moderating effects of political skill and leader-member exchange on the relationship between organizational politics and affective commitment. Journal of Business Ethics, 116, 587-599. http://dx.doi.org/10.1007/s10551-012-1497-x

Lafleur, L., Soileau, J., Soileau, L., \& Summers, G. (2012). 2012 healthcare internal auditing survey. $\quad$ Retrieved from http://www.resourcenter.net/images/AHIA/Files/2012/2012HealthcareInternalAuditingSurvey .pdf

Leroy, H., Palanski, M., \& Simons, T. (2012). Authentic leadership and behavioral integrity as drivers of follower commitment and performance. Journal of Business Ethics, 107, 255-264. http://dx.doi.org/10.1007/s10551-011-1036-1

Long, C. S., \& Thean, L. Y. (2011). Relationship between leadership style, job satisfaction and employees' turnover intention: A literature review. Research Journal of Business Management, 5, 91-100. http://dx.doi.org/10.3923/rjbm.2011.91.100

Martin, K. D., \& Hill, R. (2013). Life satisfaction, self-determination, and consumption adequacy at the bottom of the pyramid. Journal of Consumer Research, 38, 78-91. http://dx.doi.org/10.1086/661528 
McGuire, D., \& McLaren, L. (2009). The impact of physical environment on employee commitment in call centers. Team Performance Management, 15, 35-48. http://dx.doi.org/10.1108/13527590910937702

Meyer, J. P., \& Allen, N. J. (2004). TCM employee commitment survey [Academic user guide 2004]. Published instrument. Retrieved from http://employeecommitment.com/academic-license.html

Meyer, J. P., \& Maltin, E. R. (2010). Employee commitment and well-being: A critical review, theoretical framework and research agenda. Journal of Vocational Behavior, 77, 327-337. http://dx.doi.org/10.1016/j.jvb.2010.04.007

Meyer, J. P., \& Parfyonova, N. M. (2010). Normative commitment in the workplace: A theoretical analysis and re-conceptualization. Human Resource Management Review, 20, 283-294. doi:10.1234/12345678

Meyer, J. P., Stanley, D. J., Herscovitch, L., \& Topolnytsky, L. (2002). Affective, continuance and normative commitment to the organization: A meta-analysis of antecedents, correlates and consequences. Journal of Vocational Behavior, 62, 20-52. http://dx.doi.org/10.1006/jvbe.2001.1842

Morrow, P. C. (2011). Managing organizational commitment: Insights from longitudinal $\begin{array}{lllll}\text { research. Journal of } & \text { Vocational } & \text { Behavior, } & 79,\end{array}$ http://dx.doi.org/10.1016/j.jvb.2010.12.008

Owolabi, A. B. (2012). Effect of organizational justice and organizational environment on turn-over intention of health workers in Ekiti state, Nigeria. Research in World Economy, 3, 28-34. http://dx.doi.org/10.5430/rwe.v3n1p28

Qamar, N. (2012). Job satisfaction and organizational commitment as antecedents of organizational citizenship behavior (OCB). Interdisciplinary Journal of Contemporary Research in Business, 4, 103-122. Retrieved from http://ijcrb.webs.com/

Rashid, H., \& Raja, N. (2011). Mediating effect of corporate culture on the relationship of retention factors to organizational commitment. Interdisciplinary Journal of Contemporary Research in Business, 3, 211-225. Retrieved from http://ijcrb.webs.com

Rehman, S., Shareef, A., Mahmood, A., \& Ishaque, A. (2012). Perceived leadership styles and organizational commitment. Interdisciplinary Journal of Contemporary Research in Business, 4, 616-626. Retrieved from http://ijcrb.webs.com

Robson, M., Schlegelmilch, B., \& Bojkowszky, B. (2012). Resource deployment stability and performance in international research-and-development alliances: A self-determination theory explanation. Journal of International Marketing, 20(1), 1-18. http://dx.doi.org/10.1509/jim.11.0072

Sani, A. (2013). Role of procedural justice, organizational commitment and job satisfaction on job performance: The mediating effects of organizational citizenship behavior. International Journal of Business \& Management, 8, 57-67. 
http://dx.doi.org/10.5539/ijbm.v8n15p57

Soumyaja, D., Kamalanabhan, T. J., \& Bhattacharyya, S. (2011). Employee commitment to organizational change: Test of the three-component model in Indian context. Journal of Transnational Management, 16, 239-251. http://dx.doi.org/10.1080/15475778.2011.623654

Srivastava, S. (2013). Job satisfaction and organizational commitment relationship: Effect of personality variables. Vision, 17, 159-167. http://dx.doi.org/10.1177/0972262912483529

Taing, M., Granger, B., Groff, K., Jackson, E., \& Johnson, R. (2011). The multidimensional nature of continuance commitment: Commitment owing to economic exchanges versus lack of employment alternatives. Journal of Business \& Psychology, 26, 269-284. http://dx.doi.org/10.1007/s10869-010-9188-z

Van Dyk, J., \& Coetzee, M. (2012). Retention factors in relation to organizational commitment in medical and information technology services. South African Journal of Human Resource Management, 10(2), 1-11. http://dx.doi.org/10.4102/sajhrm.v10i2.433

Yücel, İ. (2012). Examining the relationships among job satisfaction, organizational commitment, and turnover intention: An empirical study. International Journal of Business \& Management, 7, 44-58. http://dx.doi.org/10.5539/ijbm.v7n20p44

\section{Copyright Disclaimer}

Copyright for this article is retained by the author(s), with first publication rights granted to the journal.

This is an open-access article distributed under the terms and conditions of the Creative Commons Attribution license (http://creativecommons.org/licenses/by/3.0/). 